\title{
GEOMETRICAL MODEL OF LEMON FRUIT
}

\author{
Leszek Mieszkalski * \\ Institute of Production Organization and Engineering, Warsaw University of Life Sciences \\ "Corresponding author: e-mail: mieszko@poczta.fm
}

\begin{tabular}{|c|c|}
\hline ARTICLE INFO & ABSTRACT \\
\hline $\begin{array}{l}\text { Article history: } \\
\text { Received: December } 2016 \\
\text { Received in the revised form: } \\
\text { January } 2017 \\
\text { Accepted: April } 2017 \\
\end{array}$ & \multirow{2}{*}{$\begin{array}{l}\text { A proposal of a mathematical method of modelling of the lemon shape } \\
\text { with Bézier's curves was presented. Lisbon, Verna, Genoa lemon } \\
\text { cultivars were selected for verification of the modelling method. The } \\
\text { lemon contour, which is its meridian, was described with three } \\
\text { smoothly combined Bézier's curves. Pictures taken in } 10 \text { locations } \\
\text { changing every 36o were the basis for description of lemon contours. } \\
\text { Bézier's curves, which approximate meridians located on the surface } \\
\text { of lemons, are their 3D models. The presented method may be applied } \\
\text { for mathematical modelling of the lemon shape. }\end{array}$} \\
\hline $\begin{array}{l}\text { Key words: } \\
\text { Lemons; shape; Bezier's curves; } \\
\text { mathematical models }\end{array}$ & \\
\hline
\end{tabular}

\section{Introduction}

Lemon is a source of health-supporting elements (Al-Juhaimi and Ghafoor, 2013, Burt, 2004; Ortuño et al.,, 2006; Mohanapriya et al., 2013). Lemon is also a raw material for industry on account of regular cellulose chain units which occur in cell walls (RondeauMouroa et al., 2003).

According to Lino et al., (2008) for assessment of the fruit quality one should determine their size, shape, mass, firmness, colours and mechanical damage. Those authors for assessment of the fruit quality suggest software called Image J, which enables calculation of volume, surface area, diameters, detection of edges. According to Khojastehnazhand et al., (2010) and Baradaran Motie et al., (2014) Taheri-Garavand and Nassiri (2010) colour and size are the most important parameters of precise classification and sorting of citrus fruit. In their opinion, the relation between physical properties of lemons and their mass are significant in designing packagings. The volume was calculated with the assumption that the lemon shape is similar to an ellipsoid and elongated spheroid. Description and estimation of the fruit shape in the form of a mathematical model is indispensable for forecasting efficiency, computer simulation of processes (storage, separation, transport etc.) and for physiological tests. Shape in the assessment of fruit and their classification and sorting plays a significant role (Kakadiya et al., 2015; Moreda et al.., 2012; Rakun et al., 2012; Iqbal et al., 2011). It is also important for the use of vision systems. Swapnil and Dale (2016) as well as Seng and Mirisaee (2009) suggested the system of automatic detection and sorting 
of fruit with a machine vision technique. Precision of the fruit recognition system, classification and their identification is at the level up to $90 \%$. The system suggested by Satya Priya and co-authors (2016) and Lalitha et al., (2015) automatically detects and efficiently diagnoses lemon diseases in their early stage of development based on the processed digital images of lemon leaves. Bozokalfa and Kilic (2010) developed an analytical method of forecasting the volume of fruit without the need to destroy it. Length, diameter and mass are independent variables. Designers of warehouses and cool houses may use the fruit shape models for assessment of the impact of mechanical loads on the bed heights and the impact of air flow characteristics on their cooling manner (Ghulam, 2015). Mebatsion et al., (2011) suggested the procedure of the shape description of symmetrical fruit with longitudinal contours, which were described with Fourier's descriptors using algorithms which smooth the fruit and vegetable surface area. Contours of cross sections of the investigated objects were described with curves B - spline. Uyar and Erdoğdu (2009) as well as Anders et al., (2014) used technique of $3 D$ scanning for description of the fruit shape. Reconstruction of a single biological object with $3 D$ scanning requires many scans to be made and it cannot be generalized as in case of mathematical models. Shape description techniques are based on simplified $3 D$ models of e.g.: a sphere, ellipsoid (Ho et al., 2011) do not ensure precise information on the shape. The solid model which was developed analytically or based on $3 D$ scans includes more information on the shape, which may result with better design decisions.

Although, there are many studies concerning the size of fruit (Tao et al., 1990; Sarkar et al., 1985; Guyer et al., 1993; Dickson et al., 1994), shape, colour (Ruiz et al., 1995; Alchanatis et al., 1993), damages (Growe and Delwiche, 1996; Miller and Delwiche, 1991; Moltó et al., 1991), then still there is a demand for works based on 3D modelling. Therefore, we should look for simple methods of imaging which will provide data on the lemon shape with more detail.

Biological objects have a considerable variability of shape and thus 3D models are developed for each object of a particular population which include information on its shape e.g. in the triangular network method: coordinates of peaks.

The objective in the paper is a method presenting the manner of proceeding aiming at description of a shape of each modelled lemon by determination of the location of the network nodes forming its skeleton. The model was shaped in case of the selected lemons of Lisbon, Verna, Genoa cultivars with the use of Bézier's curves.

\section{Material and methods}

Material for tests consisted of Lisbon lemon (length $100 \mathrm{~mm}$, width $66.2 \mathrm{~mm}$ ans thickness $64.4 \mathrm{~mm}$ ), Verna (length $103.1 \mathrm{~mm}$, width $68.9 \mathrm{~mm}$ and thickness $68.5 \mathrm{~mm}$ ), Genoa (length $83 \mathrm{~mm}$, width $72.3 \mathrm{~mm}$ and thickness $71.1 \mathrm{~mm}$ ). Lemons were purchased in a wholesale centre in Bronisze. They were stored in a room with a constant temperature of 
Geometrical model...

$19^{\circ} \mathrm{C}$ and air moisture $63 \%$. Symbols of basic dimensions of lemons ( $h$ - length, $a$ - width and $b$-thickness) and a test stand were presented in figure 1. Length, width and thickness of lemons were measured with a calliper with precision up to $0.1 \mathrm{~mm}$.

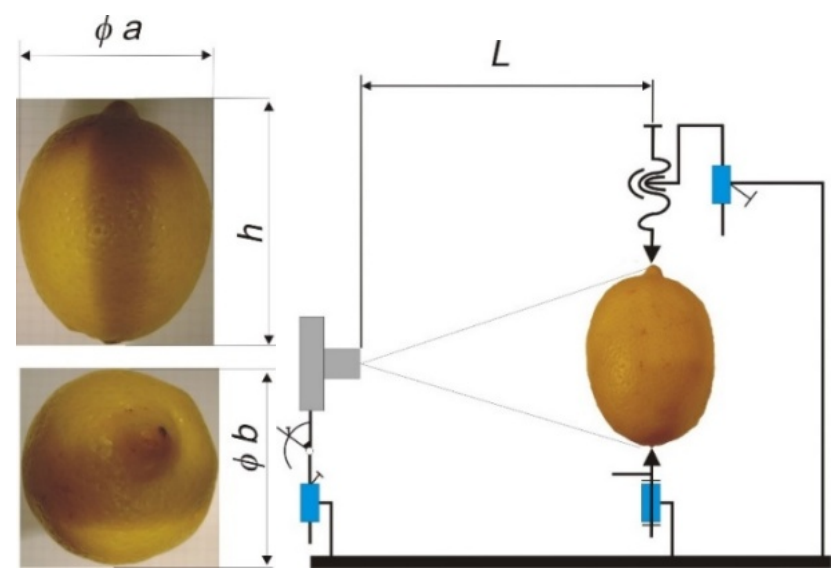

Figure1. Symbols of basic dimensions of lemons and a test stand

In order to take a picture, each lemon was placed in a test stand (Fig. 1). The test stand enabled rotation of lemons every $36^{\circ}$ towards its natural axis of symmetry. Panasonic LUMIX DMC-TZ3 camera (lens 4.6 to $48 \mathrm{~mm}$, matrix 7200000 pixels). Distance of lens from a lemon was constant and it was $400 \mathrm{~mm}$. A picture with a dimension of an image $2560 \mathrm{x}$ 1920 pixels was saved in JPEG format. Lisbon, Verna, Genoa lemons selected for modelling were presented in figure 2.
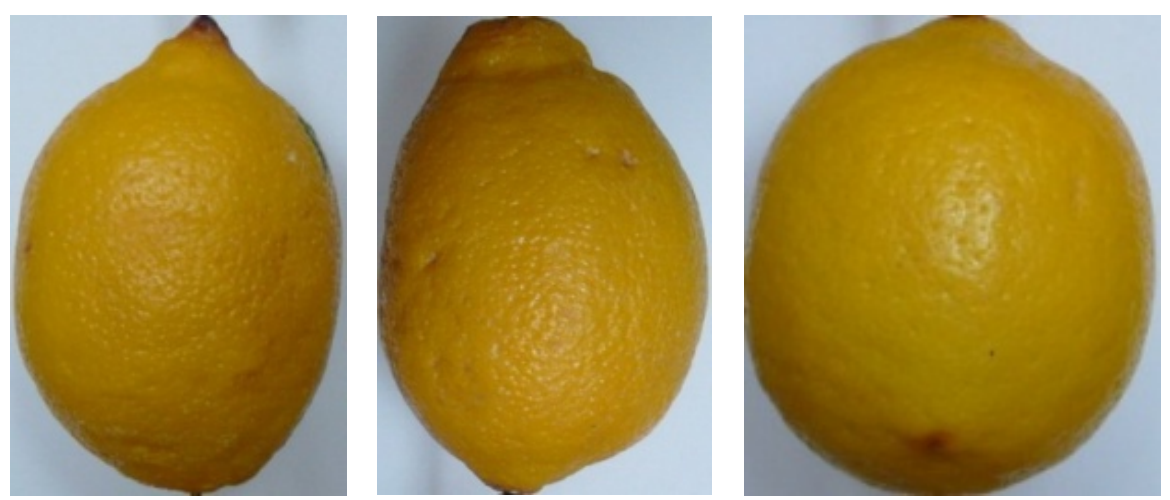

Figure 2. Lisbon, Verna, Genoa lemons selected for modelling 
Pictures of lemons were cropped and loaded to Inkscape graphical program. After the coordinate system was placed in a photo, scaling was made, then three smoothly combined Bézier's curves were adjusted on one side of the natural axis of symmetry (Fig. 3).

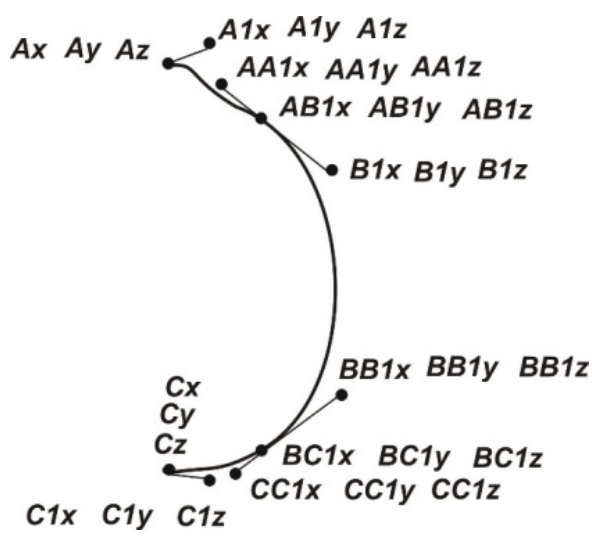

Figure 3. Symbols of node and control points of three smoothly combined Bézier's curves describing the lemon contour

Values of coordinates of four node points (eight variables) and six control points (twelve variables) are required for description of those curves. Node points of curves cover the lemon contours while the control points are outside the contour in the same plane. Change of the value of at least one coordinate of a node and control points causes a change of the curve shape. On account of a big number of variables which influence the shape of curves, a manual setting of location of node and control points was made with the use of Inkscape program. After the curves were placed on the contours of lemons with a condition of smoothness of their connection, a shape of each curve, whose deviation from the contour in the set points does not exceed 5\%, was assumed. In order to evaluate a precision of resolution of lemons, lengths between lemon edges and edges of their model in plane $X Z$ measured in cross sections each $10 \mathrm{~mm}$ were defined with their models. Inkscape computer program was selected because it ensures a possibility of scaling and measurement of coordinates of characteristic points of curves and contours for the entire cross-section.

\section{Model of lemon fruit contours represented with Bézier's curves}

Contours of lemons were described with Bézier's curves (third degree polynomials) with matrix equations of points coordinates which belong to their contours. Equations of Beézier's curve for some lemon contours are as follows: 
Geometrical model...

$$
\begin{gathered}
x \operatorname{Cn}(t)=T \cdot M \cdot P x^{T} \cdot \cos \left(\frac{\alpha n \cdot \pi}{180}\right) \\
y C n(t)=T \cdot M \cdot P y^{T} \cdot \sin \left(\frac{\alpha n \cdot \pi}{180}\right) \\
z C n(t)=T \cdot M \cdot P z^{T}
\end{gathered}
$$

where:

$$
\begin{gathered}
T=\left[\left(\frac{t}{N}\right)^{3}\left(\frac{t}{N}\right)^{2} \frac{t}{N} \quad 1\right] \\
M=\left[\begin{array}{cccc}
-1 & 3 & -3 & 1 \\
3 & -6 & 3 & 0 \\
-3 & 3 & 0 & 0 \\
1 & 0 & 0 & 0
\end{array}\right] \\
P x=\left[\begin{array}{llll}
B C n x & C C n x & C n x & C x
\end{array}\right] \\
P y=\left[\begin{array}{llll}
B C n y & C C n y y & C n y & C y
\end{array}\right] \\
P z=\left[\begin{array}{llll}
B C n z & C C n z & C n z & C z
\end{array}\right]
\end{gathered}
$$

for:

$N=23$ (decides on the number of points on plot $3 D$ ), $t \in[0, N]$,

$n$ - number of Bézier's curve,

$n=1,2,3, \ldots, 11 . \alpha n=0^{\circ}, 36^{\circ}, \ldots, 360^{\circ}$.

Equations were applied for description of a bottom, central and upper part of the lemon contour. Three Bezier's curves joined in node points maintained smoothness because control points of combined curves were located on a common line. Based on equations from 1 to 3,33 combined Bézier's curves lying along the meridian of a lemon, forming its $3 D$ model, were built. In order to make $3 D$ plot closed, three curves of contour 11 cover three curves of contour 1.

\section{Models of shape of lemon fruit}

Figure 4 shows 3D surface and point models of Lisbon, Verna, Genoa lemons shape. 
a

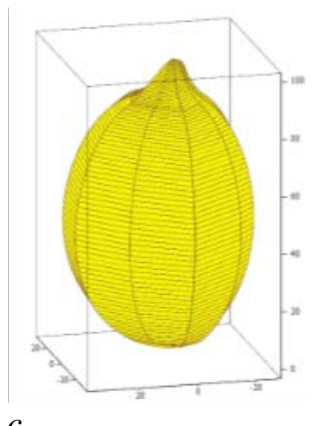

C

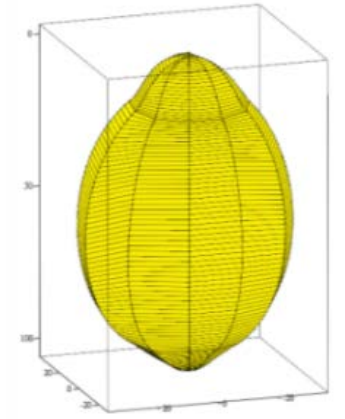

$e$

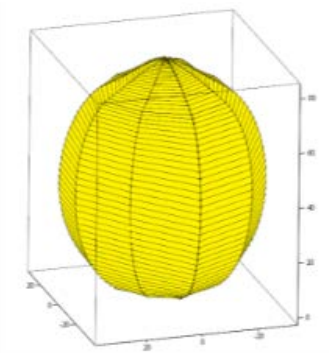

b

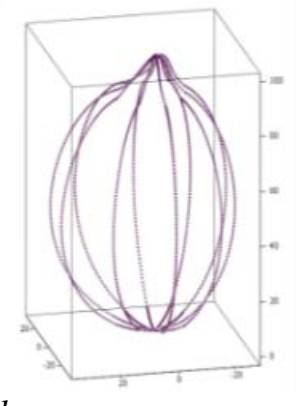

d

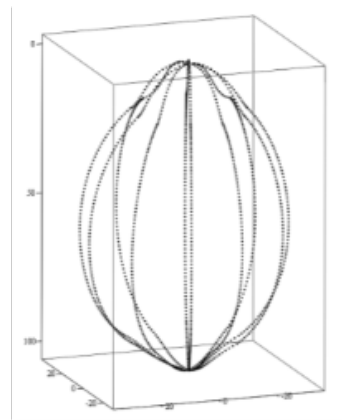

$f$

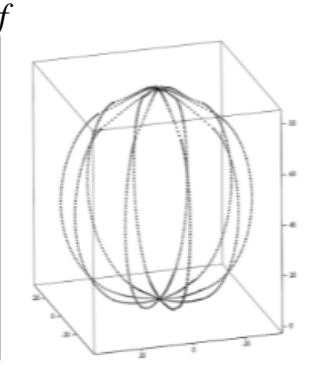

Figure 4. Models 3D of lemon shape approximated with Bézier's curves: a - surface model of Lisbon lemons, $b$ - point model of Lisbon lemon, $c$ - surface model of Verna lemon, $d$ - point model of Verna lemon, $e$-surface model of Genoa lemon , $f$ - point model of Genoa lemon

\section{Comparison of lemon fruits with their models}

In order to compare models with lemons, their selected projections in plane $X Z$ folded on each other were presented in figure 5.

As an example for the selected projections of lemons and their models, table 1 shows lengths between lemon edges and edges of their models in plane $X Z$ measured in cross sections each $10 \mathrm{~mm}$. 
Geometrical model...
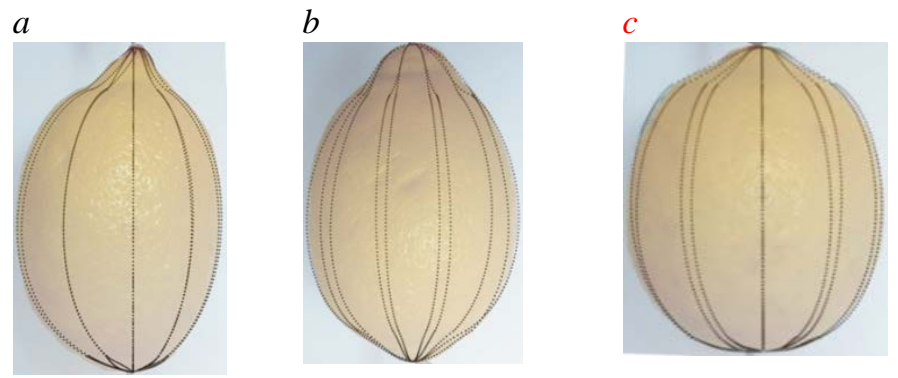

Fig. 5. Folded images of lemons and projections of their models in plane $X Z$ $a-$ Lisbon cultivar, $b$ - Verna cultivar, c-Genoa cultivar

Figure 5. Folded images of lemons and projections of their models in plane XZ a- Lisbon cultivar, $b$ - Verna cultivar, $c$ - Genoa cultivar

Table 1.

Distances between lemon edges and edges of their models in plane XZ

\begin{tabular}{|c|c|c|c|}
\hline Cultivar & $\begin{array}{l}\text { Height of } \\
\text { cross-section } \\
(\mathrm{mm})\end{array}$ & $\begin{array}{l}\text { Distances between the lemon edge } \\
\text { and the model edge on the left side } \\
\text { (mm) }\end{array}$ & $\begin{array}{l}\text { Distances between lemon edge } \\
\text { and model edge on the right side } \\
\text { (mm) }\end{array}$ \\
\hline \multirow{9}{*}{ Lisbon } & 10 & 1.8 & 0.4 \\
\hline & 20 & 1.3 & 0.2 \\
\hline & 30 & 0.1 & 0.2 \\
\hline & 40 & 0 & 0.2 \\
\hline & 50 & 0.1 & 0.1 \\
\hline & 60 & 1.1 & 0.4 \\
\hline & 70 & 1.3 & 1.1 \\
\hline & 80 & 1.3 & 0.1 \\
\hline & 90 & 0 & 0.9 \\
\hline \multirow{10}{*}{ Verna } & 10 & 1.1 & 0.2 \\
\hline & 20 & 0.1 & 0.5 \\
\hline & 30 & 0 & 0 \\
\hline & 40 & 0 & 0 \\
\hline & 50 & 0 & 0 \\
\hline & 60 & 0.2 & 0 \\
\hline & 70 & 0.9 & 0.4 \\
\hline & 80 & 2.1 & 0 \\
\hline & 90 & 1.2 & 0.6 \\
\hline & 100 & 0.1 & 0.8 \\
\hline \multirow{8}{*}{ Genoa } & 10 & 0.5 & 0.3 \\
\hline & 20 & 1.5 & 0.5 \\
\hline & 30 & 1.5 & 0.9 \\
\hline & 40 & 1 & 0.6 \\
\hline & 50 & 0.7 & 0.3 \\
\hline & 60 & 0 & 0.2 \\
\hline & 70 & 0 & 1 \\
\hline & 80 & 0.5 & 1 \\
\hline
\end{tabular}


Description of lemon contours with Bézier's contours based on the photo of a rotating lemon towards its natural symmetry axis each $36^{\circ}$ may serve for building a $3 D$ model of its shape. 33 combined Bézier's curves placed on the surface will suffice for representation of the lemon shape. The comparison of lemons with $3 D$ models shows that their adjustment is precise. The biggest differences of distance between lemon edges and edges of their models are: Lisbon lemon $1.8 \mathrm{~mm}$, Verna lemon $2.1 \mathrm{~mm}$, Genoa $1.5 \mathrm{~mm}$. Maximum deviations appear only locally.

\section{Conclusion}

The suggested method with the use of Bézier's curves may be applied for mathematical modelling of the lemon shape of various cultivars. Smoothly combined Bézier's curves distributed along meridians of lemons may be their $3 D$ model. Precision of adjustment of a model to a lemon is great with small local deviations.

\section{References}

Alchanatis, V., Peleg, K., Ziv, M. (1993). Classification of tissue culture segments by color machine vision. JAER, 55, 299-311.

Al-Juhaimi, F.Y., Ghafoor, K. (2013). Bioactive compounds, antioxidant and physico-chemical properties of juice from lemon, mandarin and orange fruits cultivated in Saudi Arabia. Pakistan Journal Botany, 45(4), 1193-1196.

Anders, A., Markowski, P., Kaliniewicz, Z. (2014). Badanie właściwości geometrycznych i fizycznych owoców wybranych odmian gruszy na podstawie modeli numerycznych uzyskanych za pomocą skanera 3D. Zeszyty Problemowe Postępów Nauk Rolniczych, 577, 3-12.

Baradaran Motie, J., Miraei Ashtiani, S. H., Abbaspour-Fard, M. H., Emadi, B. (2014). Modeling physical properties of lemon fruits for separation and classification. International Food Research Journal, 21(5), 1901-1909.

Bozokalfa, M. K., Kilic, M. (2010). Mathematical modeling in the estimation of pepper (Capsicum annum L.) fruit volume. Chilean Journal of Agricultural Research, 70(4), 626-632.

Burt, S.A. (2004). Essential oils: Their antibacterial properties and potential applications in foods: Av review. International Joutnal of Food Microbiology, 94, 223-253.

Ghulam, M. (2015). Date Fruites Classification Using Texture Descriptors and Shape-Size Features. Engineering Applications of Artificial Intelligence, 37, 361-367.

Growe, T. G., Delwiche, M. J. (1996). A system for fruit defect detection in real-time. AGENG, 96F-023.

Guyer, D.E., Miles, G. E., Gaultney, L. D., Schereiber, M. M. (1993). Application of machine vision to shape analysis in leaf and plant identification, TASAE, 36(1), 163-171.

Ho, Q. (2011). A Three-Dimensional Multiscale Model for Gas Exchange in Fruit. Plant Physiology, 155(3), 1158-1168.

Iqbal, S., Gopal, A., Sarma, A. (2011). Volume Estimation of Apple Fruits Using Image Processing. 2011 International Conference on Image Information Processing, Himachal Pradesh, 1 -6.

Kakadiya, D., Shah, R., Shah, N., Kachariya, C., Patel, M., Sukhwani, K. (2015). Shape Extraction Methods for Fruits: Technical Review. International Journal of Computer Applications, 111(1), 43-48.

Khojastehnazhand, M., Omid, M., Tabatabaeefar, A. (2010). Development of a lemon sorting system based on color and size. African Journal of Plant Science, 4(4), 122-127. 
Geometrical model...

Lalitha, K., Muthulakshmi, K., Vinothini, A. (2015). Proficient acquaintance based system for citrus leaf disease recognition and categorization. International Journal of Computer Science and Information Technologies, 6(3), 2519-2524.

Lino, A.C.L., Sanches, J., Fabbro, I.M.D. (2008). Image processing techniques for lemons and tomatoes classification. Bragantia, Campinas, 67(3), 785-789.

Mebatsion, H.K., Boudon, F., Godin, C., Pradal, C., Génard, M., Goz-Bac, C., Bertin, N. (2011). A novel profile based model 415 for virtual representation of quasi-symmetric plant organs. Computers and Electronics in Agriculture, 75(1), 113-124.

Miller, B. K., Delwiche, M. J. (1991). Peach defect detection with machine vision. TASAE, 34(6), 2588-2597.

Mohanapriya, M., Ramaswamy, L., Rajendran, R. (2013). Health and medicinal properties of lemon (Citrus limonum). International Journal Of Ayurvedic And Herbal Medicine, 3(1), 1095-1100.

Moltó, E., Aleixos, N., Ruiz, L. A., Vázquez, J., Juste, F. (1996). An artificial vision system for fruit quality assessment. AGENG 96, Madrid, 96F-078.

Moreda, G.P., Muñoz, M.A., Ruiz-Altisent, M., Perdigones, A. (2012). Shape determination of horticultural produce using two-dimensional computer vision-A review. Journal of Food Engineering, 108(2), 245-261.

Ortuño, A.A., Baidez, P., Gomez, M.C., Arcas, I., Porras, A.G., Del Rio, J.A. (2006). Citrus paradise and Citrus sinensis flavonoids: Their influence in the defence mechanism against Penicilliumdigitatum. Food Chemistry, 98(2), 351-358.

Rakun, J. (2012). Detecting Natural Objects by Means of 2D and 3D Shape Analysis. Optija, Croatia, 345-354.

Rondeau-Mouroa, C., Bouchetb, B., Pontoirea, B., Roberta, P., Mazoyerc, J., Buléona, A. (2003) Structural features and potential texturising properties of lemon and maize cellulose microfibrils. Carbohydrate Polymers, 53, 241-252.

Ruiz, L. A., Moltó, E., Juste, F., Aleixos, N. (1995). Aplicación de métodosópticos para la inspecciónautomática de productoshortofrutícolas, VI Congreso de la Sociedad Española de Ciencias Hortícolas, Barcelona.

Sarkar, N., Wolfe, R.R. (1985). Feature extraction techniques for sorting tomatoes by computer vision. TASAE, 28(3), 970-974.

Satya Priya, N., Nivetha, E., Khilar, R. (2016). Efficient Knowledge Based System to Detect Diseases in Lemon Leaf. Imperial Journal of Interdisciplinary Research (IJIR), 2(5), 275-280.

Seng, W.C., Mirisaee, S.H. (2009). A new method for fruits recognition system. Conference: Electrical Engineering and Informatics. ICEEI '09. International Conference on, 01, 130-134.

Swapnil, S.P., Dale, M.P. (2016). Computer vision based fruit detection and sorting system. Special Issue on International Journal of Electrical, Electronics and Computer Systems, ISSN (Print): 2347-2820 V-4 I-2. For 3rd National Conference on Advancements in Communication, Computing and Electronics Technology [ACCET-2016]

Taheri-Garavand, A., Nassiri, A. (2010). Study on some morphological and physical Characteristics of sweet lemon used in mass models. International Journal of Environmental Sciences, 1(4), 580-590.

Tao, Y., Morrow, C. T., Heinemann, P. H., Sommer, J. H. (1990). Automated machine vision inspection of potatoes. American Society of Agricultural Engineers, 90-3531, 23-27.

Uyar, R., Erdoğdu, F. (2009). Potential use of 3-dimensional scanners for food process modeling. Journal of Food Engineering, 93, 337-343. 


\section{GEOMETRYCZNY MODEL OWOCÓW CYTRYN}

Streszczenie. Przedstawiono propozycję metody matematycznego modelowania kształtu cytryn z wykorzystaniem krzywych Béziera. Do weryfikacji metody modelowania wybrano cytryny odmian Lisbon, Verna, Genoa. Kontur cytryny, który jest jej południkiem, opisano trzema gładko połączonymi krzywymi Béziera. Podstawą do opisu konturów cytryn są ich fotografie wykonane w 10 zmieniających się co $36^{\circ}$ położeniach. Krzywe Béziera aproksymujące południki leżące na powierzchni cytryn są ich modelami $3 D$. Przedstawiona metoda może być stosowana do matematycznego modelowania kształtu cytryn.

Słowa kluczowe: cytryny, kształt, krzywe Béziera, modele matematyczne 